\title{
EFFECT OF ELECTRODE DISTANCE AND VOLTAGE ON CR, COD, AND TSS REDUCTION IN WASTEWATER TANNING INDUSTRY USING ELECTROCOAGULATOR BATCH
}

\author{
Harimbi Setyawati ${ }^{1 *}$, Dinda Galuh ${ }^{1}$, Erni Yunita ${ }^{2}$ \\ ${ }^{1}$ Chemical Engineering, National Institute of Technology (ITN) Malang, Indonesia \\ ${ }^{2}$ Industrial Engineering, National Institute of Technology (ITN) Malang, Indonesia
}

*Corresponding Email: arimbisetva@ yahoo.co.id

\begin{abstract}
Wastewater from the tanning industry has relatively high $\mathrm{Cr}$, COD, and TSS metal pollutants. According to the regulation of the Minister of Environment of the Republic of Indonesia No. 5 of 2014 concerning the quality standard of wastewater for industrial activities, the standard quality value is $0.6 \mathrm{mg} / \mathrm{L}$ of $\mathrm{Cr}, 110 \mathrm{mg} / \mathrm{L}$ of COD, and $60 \mathrm{mg} / \mathrm{L}$ of TSS. This research aimed to determine the effect of electrode distance and voltage on reducing $\mathrm{Cr}$, COD, and TSS levels in the wastewater from the tanning industry using batch electrocoagulation. The electrocoagulation method used in this research with fixed variables was the number of 2 plate electrodes and the changing variables; it was the distance between the electrodes $(1,1.5,2,2.5$ and $3 \mathrm{~cm})$ and the electric voltage $(3,6$ and 9 volts). The research was conducted on a laboratory scale in batches with a capacity of 10 litres. The electrodes used were aluminium ( $\mathrm{Al})$ as the anode and the cathode in plates. The analysis showed that the highest percentage reduction in COD reached $88.8889 \%$ and the highest $\mathrm{Cr}$ reached $83.4712 \%$ occurred at a distance of $2 \mathrm{~cm}$ with 9 volts voltage, the highest percentage reduction in TSS reached $85.0746 \%$ with a distance of $3 \mathrm{~cm}$ with 9 volts voltage. From the results of this research, it could be concluded that the electrocoagulation method in the batch electrocoagulator was efficient enough to reduce the levels of Cr, COD, and TSS with variable electrode distance and electric voltage.
\end{abstract}

Keywords: Batch electrocoagulator, electrocoagulation, $\mathrm{Cr}$, COD, TSS

\section{Introduction}

One of the fastest-growing industries in Indonesia is the tanning industry. The tanning industry is an industry that processes leather from raw goods into semi-finished goods or finished goods in the industry derived from animal skin. There are three processes in the tanning industry, including Beam house, Tanning, and finishing [1].

Industrial waste disposed of into the environment can cause damage to the ecosystem when the waste is not processed first or the processing is not carried out thoroughly. One of the wastes that can pollute the environment is a liquid waste. Wastewater is water that has been used in an activity originating from households, industries, and other places [2].

In general, wastewater contains materials that can endanger the health of the human body and can disrupt the ecosystem. Wastewater generated from the tanning industry can cause lung cancer, liver damage, and kidney damage because it contains high enough chromium in the range of
1300-2500 ppm. According to the Minister of Environment Regulation of the Republic of Indonesia Number 5 of 2014, the maximum chromium content for the tanning industry is 0.6 $\mathrm{mg} / \mathrm{L}$. If the chromium content exceeds the quality standard, it is necessary to treat wastewater [3].

Wastewater treatment is an effort to reduce the composition of pollutants in wastewater so that it is safe to dispose of into water media, especially in tannery liquid waste containing heavy metal chromium [4]. The initial Characteristics of the Effluent of Tannery Process Liquid Waste and Quality Standard Value [1].

Table 1 Initial Characteristics of Tannery Process Liquid Waste Effluent

\begin{tabular}{c|c|c}
\hline Parameter & Effluent & $\begin{array}{c}\text { Quality } \\
\text { standards }\end{array}$ \\
\hline TSS (mg/l) & 252 & 60 \\
COD (mg/l) & 5742 & 110 \\
$\begin{array}{c}\text { Total Chrome } \\
(\mathrm{mg} / \mathrm{l})\end{array}$ & 303.75 & 0.6 \\
\hline
\end{tabular}


This research aimed to determine the effect of electrode distance and electric voltage on reducing the levels of $\mathrm{Cr}$, COD (Chemical Oxygen Demand), and TSS (Total Suspended Solid) in industrial wastewater using batch electrocoagulator. Based on the reduction in levels data, the per cent reduction in chromium, COD, and TSS levels can be calculated in the electrocoagulator.

\section{Research Method}

The waste used comes from a final disposal tank that has been treated with waste processing in the PT Nasional Djawa Kulit tanning industry. This research used the variable distance between electrode plates, consisting of $1 ; 1.5 ; 2 ; 2.5$ and $3 \mathrm{~cm}$ as shown in Figure 2; the electrodes used were made of aluminium, and the voltages were 3,6 , and 9 volts. While the fixed variable was the contact reaction time of 30 minutes with a monopolar circuit, this variable was chosen because from previous researches; this variable was the best for reducing the levels of tannery waste.

The basic principle of electrocoagulation is the reaction of reduction and oxidation (redox). In an electrocoagulation cell, oxidation occurred at the anode, whereas reduction occurred at the cathode. In electrocoagulation reactions apart from electrodes, also involved treated water which functioned as an electrolyte solution. If two electrodes were placed in an electrolyte and a direct electric current was applied, an electrochemical event would occur; it was a symptom of electrolyte decomposition, where positive ions (cations) moved to the cathode and received reduced electrons and negative ions (anions) moved to the anode and gave the oxidized electrons. An electrode made of aluminum (Al) was used for the electrocoagulation process because this metal had good coagulant properties [5].

The reaction was as follows:

On the Positive Electrode (anode)

$\mathrm{Al} \rightarrow \mathrm{Al}^{3+}+3 \mathrm{e}^{-}$

$2 \mathrm{H}_{2} \mathrm{O} \rightarrow 4 \mathrm{H}^{+}+\mathrm{O}^{2}+4 \mathrm{e}^{-}$

Because it released $\mathrm{e}^{-}$, it was called oxidation at the negative electrode (cathode)

$\mathrm{Al}^{3+}+3 \mathrm{e}^{-} \rightarrow \mathrm{Al}$

$2 \mathrm{H}_{2} \mathrm{O}+2 \mathrm{e}^{-} \rightarrow \mathrm{H}_{2} \mathrm{OH}$

Because it captures $\mathrm{e}^{-}$, it was called reduction. Meanwhile, on the anode surface (oxidation), the aluminium metal would release its positive electrons from the anode to bind $\mathrm{OH}^{-}$ which was negatively charged from the cathode; this was where the compound $\mathrm{Al}(\mathrm{OH})_{3}$ hydroxy radical or coagulant from the electrochemical process would be formed. Because it released $\mathrm{e}^{-}$ , then it was called oxidation.

The reaction for the formation of radical hydroxy compounds was because it captured $\mathrm{e}^{-}$, it was called reduction.

$$
\mathrm{H}_{2} \mathrm{O}+\mathrm{Al}^{3+} \rightarrow \mathrm{Al}(\mathrm{OH})_{3}+\mathrm{H}^{-}+\mathrm{e}^{-}
$$

Small bubbles $\left(\mathrm{H}_{2}\right.$ and $\left.\mathrm{O}_{2}\right)$ were released on the surface of the electrodes, which caused the electroflotation process by clots attached to the electrodes mostly carried to the surface of the water [6] as shown in Figure 1.

\section{Electrocoagulator Schematic}

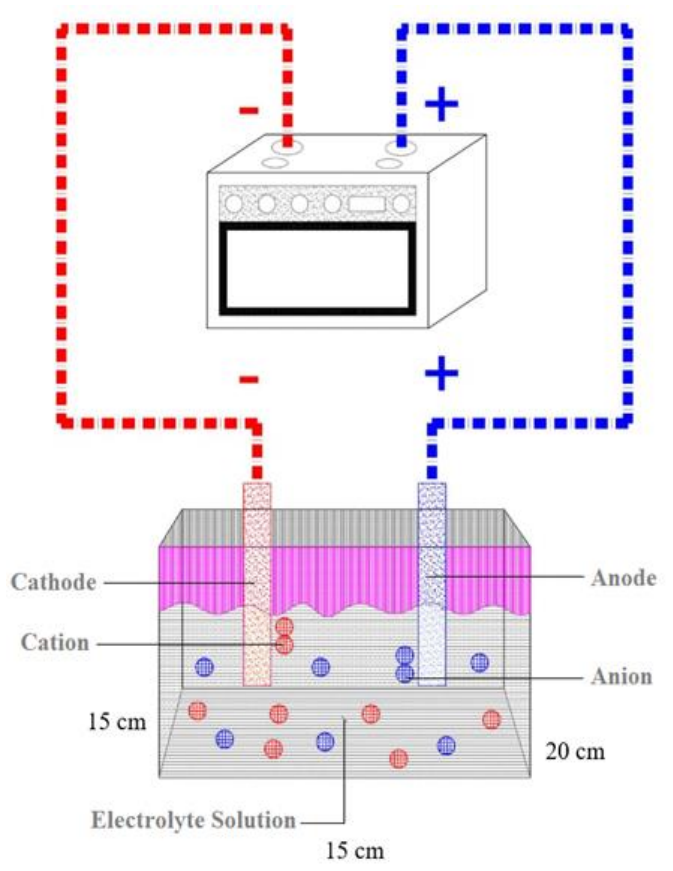

Figure 1 Electrocoagulation Tool Scheme

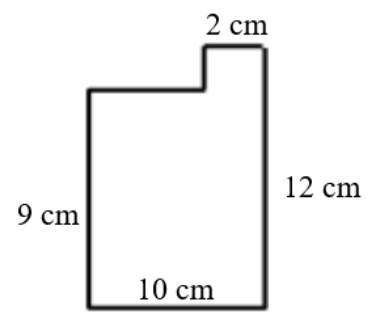

Figure 2 Aluminum Plate Electrodes 


\subsection{Research Flow Chart}

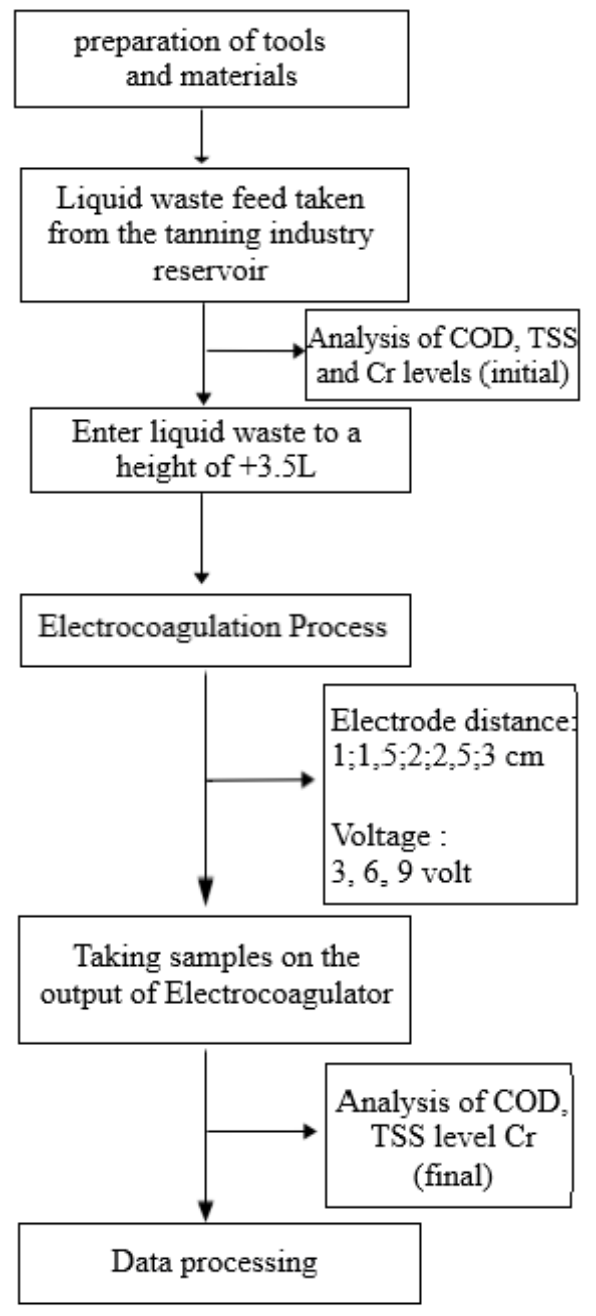

Figure 3 Flow Chart of Liquid Waste Processing with Electroangulation

\subsection{Research Results}

1. The effect of electode distance and voltage on chromium levels The data that had been obtained can be displayed as seen in Figure 4.

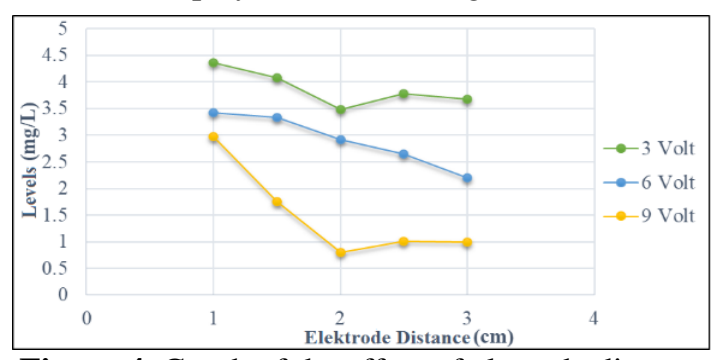

Figure 4 Graph of the effect of electode distance and voltage on chromium content
Based on the data obtained in Figure 5, the percentage of chromium removal can be calculated and can be displayed.

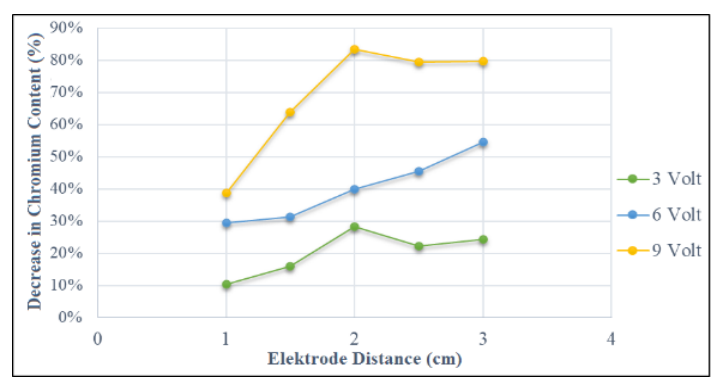

Figure 5 Graph of the effect of electrode distance and voltage on the decrease in chromium content

Based on the graph in Figure 5, it could be seen that the most significant percentage reduction in chromium content was at the voltage variable of 9 volts and a distance of $2 \mathrm{~cm}$, which was $83.4712 \%$. Meanwhile, the minor percentage reduction in chromium levels was at the variable 3 volts voltage and $1 \mathrm{~cm}$ distance, $10.3115 \%$. The graph above looked fluctuating because the voltage and electrode distance would affect the obtained results.

From the electrochemical reaction of aluminium metal as anode and cathode at the anode, gas, foam and $\mathrm{Al}(\mathrm{OH}) 3$ floc would be produced. Furthermore, the floc formed would trap electronically against the chromium metal in the waste so that the floc will tend to settle. Furthermore, the floc which had bound the Chrome contaminants settles in the tub [7].

In the electrocoagulation process, direct current (DC) was used. The more optimum the electric current used, the better the electrocoagulation process that occurred. If the electric current used was too large, it would cause the formation of $\mathrm{H} 2$ gas that was too large and too fast to break the floc that has been formed [8].

The distance between the electrodes impacts the electron transfer rate between the anode which accepts electrons and the cathode, where the reduction process occurs. The decrease in processing efficiency occurred when the distance between the electrodes was enlarged, which caused a sizeable current resistance so that the conductivity decreased. However, if the distance between the electrodes was too close, it would cause the number of coagulants to increase so that the system was disturbed due to the short circuit between the electrodes [9].

There was a decrease in efficiency at the distance of $2.5 \mathrm{~cm}$ and $3 \mathrm{~cm}$ at a voltage of 3 volts and 9 volts in the experimental results. The results of this experiment were directly proportional to the theory above, where a decrease in processing efficiency 
occurred when the distance between the electrodes was enlarged, which caused a sizeable current resistance so that the conductivity decreased.

The standard quality level of the ministry of environment for chromium content was $0.6 \mathrm{mg} / \mathrm{L}$. This research could reduce chromium levels up to $83.4712 \%$ with an initial concentration of $4.8 \mathrm{mg} / \mathrm{L}$ to $0.8034 \mathrm{mg} / \mathrm{L}$. The experiment had not included the standard quality value due to the high levels of waste in the factory due to various things such as the lack of reaction time so that the contact time between the electrodes was not maximum, the amount of voltage was not large enough that it affected the electrocoagulation process. However, there was a significant decrease in chromium levels in this research, which was $83.4712 \%$, indicating that the electrocoagulation method was able to reduce the chromium levels found in the tanning industry.

2. The effect of electrode distance and voltage on TSS (Total Suspended Solid) levels. The data that has been obtained can be displayed as seen in Figure 7.

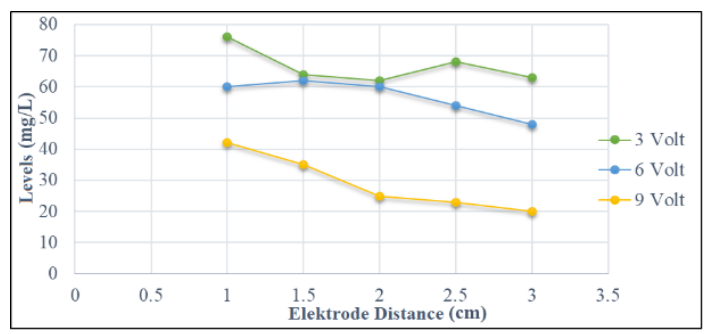

Figure 6 Graph of the effect of electrode distance and voltage on TSS levels

Based on the data that has been obtained in Figure 7 , the percentage of TSS removal could be calculated and displayed as seen.

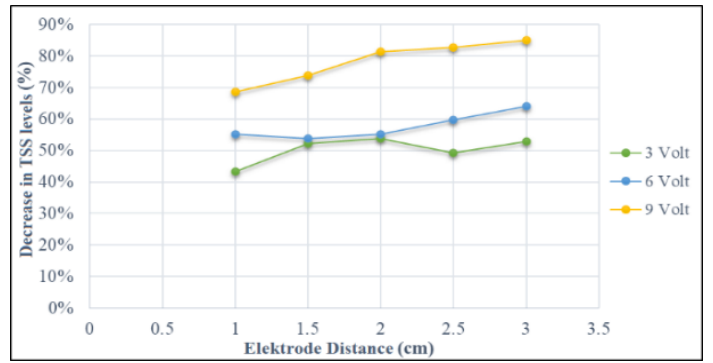

Figure 7 Graph of the effect of electrode distance and voltage on the decrease in TSS levels

Based on Figure 7, it could be seen that the most considerable percentage reduction in TSS levels was in the variable voltage of 9 volts and a distance of 3 $\mathrm{cm}$, which was equal to $85.0746 \%$. While the most negligible percentage reduction in TSS levels was at the variable voltage of 3 volts and a distance of $1 \mathrm{~cm}$, which was $43.2836 \%$. The graph above looked fluctuating because the voltage and electrode distance would affect the results obtained.

The deposition mechanism of the $\mathrm{Al}(\mathrm{OH})_{3}$ floc in the electrocoagulation bath followed the coagulation-flocculation principle due to the growth of floc mass so that the density of the floc became large and eventually settled. The distance between the electrode plates greatly affected the process of decreasing the TSS concentration. If it was connected to the distance, the experimental results were under the theory that the closer the distance between the electrodes was, the more significant the decrease in TSS concentration. The farther the distance between the electrodes, the less the electric current rotation path so that the efficiency of decreasing the TSS concentration that occurred was getting smaller [10].

The distance between the electrodes impacted the electron transfer rate between the anode that accepted electrons and the cathode, where the reduction process occurred. The decrease in processing efficiency occurred when the distance between the electrodes was enlarged, which caused a sizeable current resistance so that the conductivity decreases. However, if the distance between the electrodes was too close it would cause the number of coagulants to increase so that the system was disturbed due to the short circuit between the electrodes [11].

There was a decrease in efficiency at the distance of $2.5 \mathrm{~cm}$ and $3 \mathrm{~cm}$ at a voltage of 3 volts in the experimental results. The results of this experiment were directly proportional to the theory above, where a decrease in processing efficiency occurred when the distance between the electrodes was enlarged, which caused a sizeable current resistance so that the conductivity decreased.

The level of quality standards of the ministry of environment for TSS levels was $60 \mathrm{mg} / \mathrm{L}$. This research could reduce TSS levels up to $85.0746 \%$ with an initial concentration of $134 \mathrm{mg} / \mathrm{L}$ to 20 $\mathrm{mg} / \mathrm{L}$. The experiment had included the standard quality value so that this showed that the electrocoagulation method was able to reduce TSS levels found in the tanning industry.

3. The effect of electode distance and voltage on COD (Chemical Oxygen Demand) levels

The data that had been obtained could be displayed as seen in Figure 8. 


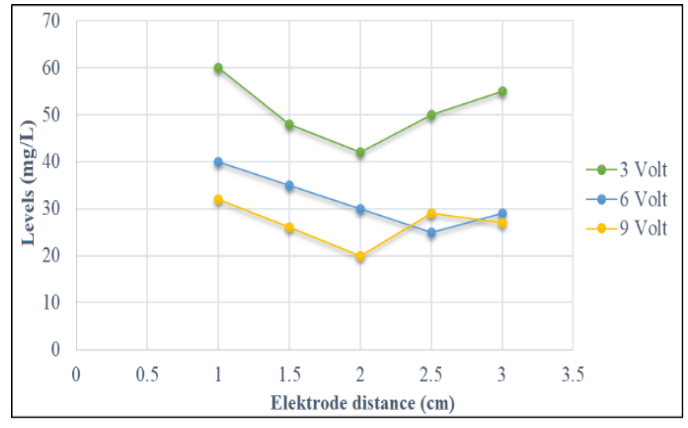

Figure 8 Graph of the effect of electrode distance and voltage on COD levels

Based on the data obtained in Figure 9, the removal percentage of COD levels could be calculated and displayed.

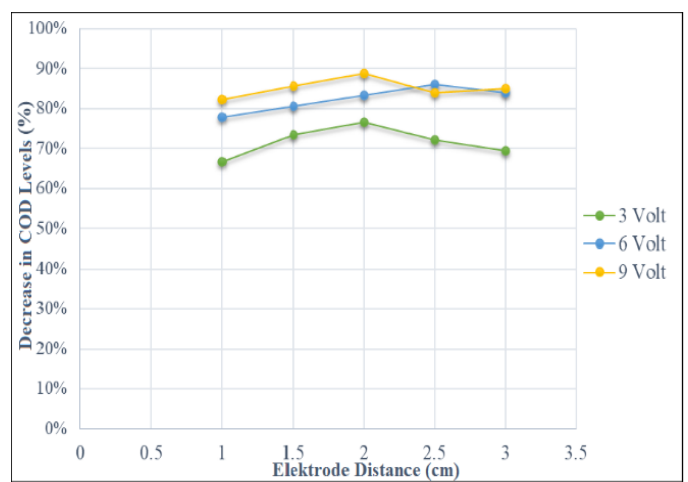

Figure 9 Graph of the effect of electrode distance and voltage on the decrease in COD levels

Based on the graph in Figure 9, it could be seen that the most considerable percentage reduction in COD levels was at the voltage variable of 9 volts with a distance of $2 \mathrm{~cm}$, amounting to $88.8889 \%$. In contrast, the most negligible percentage reduction in TSS levels was at the voltage variable of 3 volts and a distance of $1 \mathrm{~cm}$, which was $66.6667 \%$. The graph above looked fluctuating because the voltage and electrode distance would affect the results obtained.

The deposition mechanism of the $\mathrm{Al}(\mathrm{OH})_{3}$ floc in the electrocoagulation bath followed the coagulation-flocculation principle due to the growth of floc mass so that the density of the floc became large and eventually settled. The distance between the electrode plates greatly affected the process of decreasing the COD concentration. If it was connected with distance, the experimental results were under the theory that the closer the distance between the electrodes was, the greater the decrease in COD concentration. The farther the distance between the electrodes, the less the electric current rotation path so that the efficiency of the COD concentration reduction process that occured was getting smaller [10]. The efficiency of COD removal depends on the electrochemical concentration generated by the hypochlorite ion in the wastewater. When the electrolysis time was longer, more hypochlorite ions would be produced in the waste. Therefore, the colour and value of COD in the solution were reduced at higher hypochlorite concentrations [11].

The distance between the electrodes impacted the rate of electron transfer between the anode that accepted electrons and the cathode, where the reduction process occurred. The decrease in processing efficiency occurred when the distance between the electrodes was enlarged, which caused a large current resistance so that the conductivity decreased. However, if the distance between the electrodes was too close it would cause the number of coagulants to increase so that the system was disturbed due to the short circuit between the electrodes [9].

There was a decrease in efficiency at the distance of $2.5 \mathrm{~cm}$ and $3 \mathrm{~cm}$ at a voltage of 3,6, and 9 volts in the experimental results. The results of this experiment were directly proportional to the theory above, where a decrease in processing efficiency occurred when the distance between the electrodes was enlarged, which caused a sizeable current resistance so that the conductivity decreased.

The standard quality level of the ministry of environment for COD levels was $110 \mathrm{mg} / \mathrm{L}$. This research could reduce TSS levels up to $88.8889 \%$ with an initial concentration of $180 \mathrm{mg} / \mathrm{L}$ to 20 $\mathrm{mg} / \mathrm{L}$. The experiment had included the standard quality value so that this showed that the electrocoagulation method was able to reduce COD levels found in the leather tanning industry.

4. The effect of electrode distance and voltage on chromium, COD, and TSS levels From the results obtained, the best reduction levels using the electrocoagulator tool can be concluded as seen in Table 2.

Table 2 Data Comparison of Initial Analysis with Best Analysis Results

\begin{tabular}{|c|c|c|c|c|c|c|c|}
\hline \multirow[b]{2}{*}{ Parameter } & \multirow{2}{*}{$\begin{array}{l}\text { Initial } \\
\text { Level } \\
(\mathrm{mg} / \mathrm{l})\end{array}$} & \multicolumn{2}{|c|}{3 volt } & \multicolumn{2}{|c|}{6 volt } & \multicolumn{2}{|c|}{9 volt } \\
\hline & & $\begin{array}{l}\text { Final } \\
\text { Level } \\
(\mathrm{mg} / \mathrm{l})\end{array}$ & $\begin{array}{l}\text { Distanc } \\
\mathrm{e}(\mathrm{cm})\end{array}$ & $\begin{array}{l}\text { Final } \\
\text { Level } \\
(\mathrm{mg} / \mathrm{l})\end{array}$ & $\begin{array}{l}\text { Distanc } \\
\mathrm{e}(\mathrm{cm})\end{array}$ & $\begin{array}{l}\text { Final } \\
\text { Level } \\
(\mathrm{mg} / \mathrm{l})\end{array}$ & $\begin{array}{l}\text { Dista } \\
\text { nce } \\
(\mathrm{cm})\end{array}$ \\
\hline Krom & 4.86 & 3.48 & 2 & 2.20 & 3 & 0.80 & 2 \\
\hline COD & 180 & 42 & 2 & 25 & 2.5 & 20 & 2 \\
\hline TSS & 134 & 62 & 2 & 48 & 3 & 20 & 3 \\
\hline
\end{tabular}


In chromium, COD and TSS levels were at a voltage of 9 volts with an electrode distance of $2 \mathrm{~cm}$. When it was related to distance and stress, distance and stress had a significant effect on the rate of reduction in the concentration of COD, TSS, and chromium. This was because the higher the voltage used, the stronger the melting current would be even greater.

This opinion was supported by Ohm's Law which stated that the amount of electric current (I) flowing through a conductor or conductor would be directly proportional to the potential/voltage difference (V) applied to it and was inversely proportional to its resistance (R). The amount of voltage was directly proportional to the amount of electric current flowing at the electrodes. The electric current caused reduction and oxidation reactions at the electrode so that the greater the electric current, the more aluminium hydroxide or $\mathrm{Al}(\mathrm{OH})_{3}$ and $\mathrm{H}_{2}$ bubbles were formed. The higher the current density, the greater the release of $\mathrm{Al}^{3+}$ ions due to the electrolytic oxidation process. So, it could be concluded that the number of electrode plates did not have a big effect on reducing the levels of pollutants in the waste [12].

\section{Conclusion}

Based on the results of the research, the effect of electrode distance and voltage on the decrease in $\mathrm{Cr}$, COD, and TSS levels in tanning industrial wastewater using a batch electrocoagulator, the conclusions were:

- The effect of the best voltage and electrode distance on the decrease in wastewater content is that a voltage of 9 volts with an electrode distance of $2 \mathrm{~cm}$ could produce the highest reduction in waste containers with the highest reduction efficiency for $\mathrm{Cr}, \mathrm{COD}$, respectively for the value of $\mathrm{Cr}$, it was $83.47 \%$, COD $88.88 \%$, and a decrease in TSS at a voltage of 9 volts with an electrode distance of $3 \mathrm{~cm}$ can produce the highest reduction in waste containers with an efficiency of reducing levels of $85.07 \%$.

- The results obtained fluctuate because of a certain distance, resulting in a decrease in high or low levels. The closer the distance between the electrodes would cause the number of coagulants to increase, but the system will experience interference. However, if the distance is further away, the decrease in efficiency could also decrease due to the considerable current resistance to decrease the conductivity.
- $\mathrm{Cr}$ deposits resulting from the electrocoagulation process were collected and considered further to be processed to be used in the electroplating process.

\section{References}

[1] Aulianur, Rusyadi W. 2013. Perbandingan Metode Elektrokoagulasi dengan Presipitasi Hidroksida untuk Pengolahan Limbah Cair Penyamakan Kulit (Comparison of Electrocoagulation Method with Hydroxide Precipitation for Tannery Liquid Waste Treatment). Department of Agricultural Industrial Technology, Faculty of Agricultural Technology. Bogor

[2] Hiksia, Achmad. 2001. Kimia Unsur dan Radiokimia (Elemental Chemistry and Radiochemistry). Bandung. H.138

[3] Ni'am, Achmad C., dkk. 2017. Variasi Jumlah Elektroda Dan Besar Tegangan Dalam Menurunkan Kandungan Cod Dan Tss Limbah Cair Tekstil Dengan Metode Elektrokoagulasi (Variations in the number of electrodes and the amount of voltage in reducing the Cod and Tss content of textile wastewater with the electrocoagulation method). Environmental Engineering Department, Surabaya Adhi Tama Institute of Technology, Surabaya.

[4] Fardiaz, S., 1992. Polusi Air dan Udara (Water and Air Pollution), Kanisius. Yogyakarta.

[5] Ariyanto, Eko. 2016. Pengaruh Konfigurasi Elektron dan Kinetika Proses Elektrokoagulasi (Effect of Electron Configuration and Electrocoagulation Process Kinetics).

[6] Ampera, M.P.J., 2018. Penurunan Kekeruhan Air Baku IPA Badak Singa dengan Penggunaan Koagulan PAC dan Plat Aluminium pada Proses KoagulasiElektrokoagulasi (Decreasing Turbidity of Lion Rhinoceros IPA Raw Water by Using PAC Coagulant and Aluminum Plate in the Coagulation-Electrocoagulation Process). Department of Environmental Engineering, Faculty of Engineering, Pasundan University, Bandung

[7] Irene, Sildia. 2014. Penurunan Chemical Oxygen Demand (COD) pada Berbagai Macam Limbah Melalui Elektrokoagulasi (Decreasing Chemical Oxygen Demand (COD) in Various Wastes through Electrocoagulation). Jatinangor.

[8] Metcalf \& Eddy, Inc. 1991. Wastewater Engineering: treatment, disposal, reuse. 3rd ed. (Revised by: G.Tchobanoglous and F.L. 
Burton). McGraw-Hill,Inc. New York, Singapore. $1334 \mathrm{p}$.

[9] Larasti, Vellanda Aderista. 2017. Penurunan Kadar Cr, COD, dan TSS dalam Limbah Cair PT. Rajawali Tanjungsari Enjiniring Menggunakan Metode Elektrokoagulasi Katoda Silender Berputar Secara Kontinyu (Decreased levels of Cr, COD, and TSS in PT. Rajawali Tanjungsari Engineering Using the Electrocoagulation Method a Continuously Rotating Silender Cathode). Department of Chemical Engineering, State Polytechnic of Malang, Malang.

[10] Luqman, Sahlan, 2016. Penurunan Kadar Krom (Cr) dalam Limbah Cair Industri Penyamakan Kulit dengan Elektrokoagulasi secara Batch (Decreased levels of chromium $(\mathrm{Cr})$ in the liquid waste of the tannery industry using batch electrocoagulation). Veteran National Development University, Yogyakarta

[11] Abbas, Salman Hussein, and Wail Hassan Ali. 2018. Electrocoagulation Technique Used to Treat Wastewater: A Review. American Journal of Engineering Research (AJER), 7 (10), 74-88.

[12] Anggorowati, D.A., Minah, F.N., Artayani, A., Mustiadi, L., 2020. Early Study of Biocharcoal Quality from Poultry Livestock Waste. Journal of Sustainable Technology and Applied Science (JSTAS), 1(1), 7-12 https://doi.org/10.36040/jstas.v1i1.2523 